\title{
POTENTIAL SUITABLE HABITAT DISTRIBUTION FOR TWO ENDEMIC AND HIGHLY THREATENED SPECIES OF Leptophryne (AMPHIBIA; BUFONIDAE) IN JAVA
}

\section{POTENSI DISTRIBUSI HABITAT YANG SESUAI UNTUK DUA SPESIES ENDEMIK DAN SANGAT TERANCAM DARI GENUS Leptophryne (AMPHIBIA; BUFONIDAE) DI JAWA}

\author{
Pramitama Bayu Saputro, Aldio Dwi Putra, Iwan Setiawan, Tedi Setiadi \\ Pusat Informasi Lingkungan Indonesia (PILI), Jl. Tumenggung Wiradiredja No. 216, Cimahpar, Bogor \\ E-mail: bayu.pramitama@gmail.com
}

(received October 2019, revised November 2019, accepted December 2019)

\begin{abstract}
ABSTRAK
Genus Leptophryne (family Bufonidae) terdiri dari tiga spesies, yaitu L. borbonica, L. cruentata dan L. javanica. Dua spesies, L. cruentata dan L. javanica, merupakan endemik Jawa dan berkategori Kritis dan Genting, secara berurutan. Leptophryne javanica dideskripsikan pada tahun 2018 sebagai spesies yang terpisah dari L. cruentata berdasarkan perbedaan morfologi, molekular, dan karakteristik suara. Kedua spesies mempunyai tipe habitat yang sama, yaitu hutan pegunungan, air terjun dan aliran sungai berbatu. Sampai awal 2000-an, kedua spesies Leptophryne endemik diperkirakan hanya tersisa di Gn. Gede saja. Sejak tahun 2000 sampai 2018, spesies ini ditemukan juga di Gn. Halimun, Gn. Ciremai, dan Gn. Slamet. Catatan lokasi baru tersebut mengindikasikan potensi sebaran di luar lokasi yang sudah diketahui sebelumnya. Studi ini bertujuan untuk memprediksi potensi habitat yang sesuai bagi Leptophryne endemic (L. cruentata dan $L$. javanica) dan mengidentifikasi variabel lingkungan paling penting dalam mengkarakterisasi distribusi habitat spesies ini. Pemodelan MaxEnt digunakan untuk memetakan potensi habitat yang sesuai. Sebanyak 12 koordinat digunakan sebagai data kehadiran untuk pemodelan, terdiri atas 10 koordinat di Gn. Gede Pangrango, satu di Gn. Ciremai, dan satu di Gn. Slamet. Sebanyak 21 variabel lingkungan digunakan dalam pemodelan, yaitu peta tutupan lahan, ketinggian, dan 19 variabel iklim (mencakup curah hujan dan suhu), bersama data kehadiran. Hasil menunjukkan bahwa terdapat potensi habitat baru di luar lokasi sebaran saat ini, terdiri atas 14 fragmen di Jawa bagian barat, lima di tengah, dan empat di timur. Lokasi potensial cukup luas terdapat di pegunungan selatan Bandung. Variabel perubahan suhu yang kecil, dataran tinggi, rataan suhu lebih rendah selama musim yang lebih hangat, dan tutupan lahan yang lebih baik menciptakan kesesuaian habitat tebaik. Studi lebih lanjut sangat diperlukan untuk membuktikan keberadaan spesies ini pada lokasi potensial berdasarkan hasil pemodelan.
\end{abstract}

Kata kunci: Kodok merah, L. cruentata, L. javanica, Pemodelan, MaxEnt.

\begin{abstract}
Bufonid toad genus Leptophryne comprises three species; L. borbonica, L. cruentata, and L. javanica. These three species occurred in Java Island. Two out of three species, L. cruentata and L. javanica, are endemic and classified as critically endangered (CR) and endangered (EN), respectively. Leptophryne javanica recently described in 2018, and it is separated from $L$. cruentata by having distinct morphology, molecular and call characteristics. Both $L$. cruentata and $L$. javanica share the same habitat type (i.e. mountain forest, waterfall, rocky stream). Until early 2000 , these two endemic Leptophryne were considered restricted to Mt. Gede. From 2000 to 2018, these species were also recorded in Mt. Halimun, Mt. Ciremai, and Mt. Slamet. These new localities indicate that there is potential distribution outside previously known locations. This study aims to predict the potential suitable habitat of endemic Leptophryne (L. cruentata and L. javanica) and identify the most important environmental variables on its distribution. MaxEnt modelling was applied to generate a potential suitable habitat distribution map. Twelve presence data were used for the model consist of 10 coordinates in Mt. Gede Pangrango, one in Mt. Ciremai, and one in Mt. Slamet. To build the model, 21 environmental variables were utilized: land cover, altitudinal and 19 variables of precipitation and temperature along with the species presence data. The result shows there is suitable habitat outside the known locations, consist of 14 patches in western Java, five in central Java and four in eastern Java. The most potential is in the mountainous area at southern Bandung. The lowest temperature fluctuation, highest elevation, lowest mean temperature during the warmest season, and better land cover provides the best habitat suitability. Further study is required to verify these potential distributions based on the modelling result.
\end{abstract}

Key words: Bleeding toad, L. cruentata, L. javanica, Species Distribution Model, MaxEnt.

\section{INTRODUCTION}

The genus Leptophryne is a cryptic amphibian taxa that inhabit Java Island. In this genus, there are three species, of which two species are endemic to Java with very limited distribution i.e. L. cruentata dan L. javanica (Iskandar 1998; Hamidy et al. 2018). Apart from being endemic and restricted range 
species, both species are classified as highly threatened species in the IUCN Red List: L. cruentata is Critically Endangered (CR) and L. javanica is Endangered (EN) (Iskandar \& Mumpuni 2004; IUCN SSC ASG 2019). Another species (i.e. L. borbonica) has more widespread distribution encompassing Sumatra, Borneo, and the Malay-Thai peninsula (Inger 1966; Inger \& Iskandar 2005; Berry 1975 and Manthey \& Grossmann 1997 (both in Hamidy et al. 2018)).

Before 2018, L. cruentata and L. javanica were known as a single species which was L. cruentata (hereinafter both species will be referred as endemic Leptophryne). The splitting of these two endemic species is due to genetic, morphology, and call differences (Hamidy et al. 2018). The two species live in almost similar habitat characteristic, which is on the banks and the rocks of rocky stream in volcanic mountain forested area (Iskandar 1998; Hamidy et al. 2018).

The population of endemic Leptophryne is decreasing drastically (Iskandar 1998). Previously, the species was considered to be very common in Java. The drastic decreases in population numbers may be due to the eruption of Mt. Galunggung (Iskandar \& Mumpuni 2004) and pathogenic fungal infection (Kusrini et al. 2008). Besides, other potential threats are trade, tourism, geothermal development, sand mining (IUCN SSC ASG 2019), and climate change which may cause altitudinal distribution shift (Kusrini et al. 2017).

Before the 2000s, the last population of endemic Leptophryne was considered only remains in Mt. Gede Pangrango National Park (NP) region (Liem 1971; Iskandar 1998). Historical records mentioned the endemic Leptophryne occurred in several locations such as Cibeureum waterfall, Lebak Saat, Rawa Denok, Salabintana, Cipelang, Perbawati, Curug Luhur (Mt. Gede Pangrango), Sagaranten and Ciapus (Mt. Salak) (van Kampen 1923; Liem 1973; Iskandar 1998; Kusrini et al. 2007). Later, several studies succeeded in recording the presence of endemic Leptophryne in several new locations both inside Mt. Gede Pangrango NP (e.g. Citirilik; Setiawan et al. 2014a), and outside Mt. Gede Pangrango, namely in Cikeris-Mt. Halimun Salak NP (Kurniati 2003), in Cipadare river-Mt. Ciremai NP (Setiawan et al. 2014b), and in Guci tourism area-Mt. Slamet (Mumpuni 2014). The population of Mt. Ciremai NP and Mt. Slamet was identified as new species i.e. L. javanica (Hamidy et al. 2018).

Based on available evidence, new records of endemic Leptophryne in several locations outside the current known range indicate the potential for distribution in other unsurveyed (or limited surveyed) sites. This fact shows the limited and incomplete information on its distribution. Complete distribution information is essential for conservation efforts for endemic and highly threatened Leptophryne.

The limitation on distribution knowledge of endemic Leptophryne can be solved by applying species distribution modelling. Modelling aims to predict potential suitable habitat distribution outside the current known location. This method is an effective and efficient technique as an initial effort in predicting potential species distribution in a previously unknown location, especially in a region where data collection is difficult due to limited resources and inaccessible terrain (Smith et al. 2002).

Here, we predict the potential new distribution of endemic Leptophryne based on 
the availability of its suitable habitat across Java Island and identify the characteristic of the suitable habitat. We overlaid the prediction map with a conservation area map to get the impression of its potential distribution in the context of conservation effort for these highly threatened species.

\section{MATERIALS AND METHODS}

\section{Presence data}

The presence records of Leptophryne cruentata and $L$. javanica are merged as the presence of endemic Leptophryne in the analysis. The presence data is collected from a literature study that mentioned the exact location which can be georeferenced. In a total of 12 presence data including ten coordinates in Mt. Gede Pangrango (i.e. from Cibeureum waterfall and Citirilik River) (Liem 1973; Iskandar 1998; Kusrini et al. 2007; Setiawan et al. 2014a), one in Guci-Mt. Slamet (Mumpuni 2014), and one in Cilutung waterfall-Mt. Ciremai NP (Setiawan et al. 2014). The presence-only data is presented in form of geographical coordinates.

\section{MaxEnt modelling and environmental variables}

Suitable habitat distribution modelling was performed using MaxEnt (Maximum Entropy; Princenton University 2004). MaxEnt modelling produces and indicate a potential suitable habitat distribution map for target species based on certain habitat characteristics and environmental features of its present location (Hirzel et al. 2002). MaxEnt is able to determine the target species ecological niche and its potential distribution in a given region (Phillips et al. 2006). MaxEnt is a species distribution modelling with high accuracy compared to other programs, especially regarding limited species presence datasets (Hernandez et al. 2006, Phillips et al. 2006, Pearson et al. 2007).

Twenty-one environmental variables were utilized in the model consist of land cover, altitude, and 19 bioclimatic variables (comprising precipitation and temperature). Bioclimatic data were derived from WorldClim dataset (http://worldclim.org, Hijman et al., 2005), comprising: annual mean temperature, mean diurnal range, isothermality, temperature seasonality, max temperature of warmest month, min temperature of coldest month, temperature annual range, mean temperature of wettest quarter, mean temperature of driest quarter, mean temperature of warmest quarter, mean temperature of coldest quarter, annual precipitation, precipitation of wettest month, precipitation of driest month, precipitation seasonality, precipitation of wettest quarter, precipitation of driest quarter, precipitation of warmest quarter, and precipitation of coldest quarter. The altitudinal variable was extracted from http://srtm.csi.cgiar.org and the land cover variable (a mosaic from year 2015 period of Normalized Difference Vegetation Index data) from http://usgs.glovis.org. All environmental variables were resampled the WGS 84 geographical coordinated system at a resolution of $0.050 \times 0.050$ or $1 \mathrm{~km} 2$. All map processing was done using ArcGis (v.10; (C) ESRI Inc., Redlands, California). The modelling was applied to entire Java Island.

\section{Data analysis}

The model output is a map showing the potential distribution of suitable area which is linearly scaled between 0 (unsuitable) and 1 (very suitable) (Phillips \& Dudik, 2008). The relative contribution of environmental variables 
to the final model was automatically assessed by the software. To assess the performance of the model, the "area under the Receiver Operating Characteristic curve (AUC)" was used, with AUC ranging from 0-1, with values $<0.5$ as no better than random, $>0.7$ fair and 1 being a perfect fit (Fielding \& Bell 1997). The result of modelling was then used to predict suitable habitat for endemic Leptophryne in Java. The threshold of equal training sensitivity and specificity was used to distinguish between suitable and unsuitable habitat for endemic Leptophryne. The predicted suitable habitat distribution was clipped with the conservation area and Peta Rupa Bumi Indonesia.

\section{RESULTS AND DISCUSSION}

The model performed very well in predicting potential suitable habitat distribution of endemic Leptophryne in Java as expressed by the AUC value of 0.999 (Fielding \& Bell 1997). Several patches of predicted suitable habitat are found across Java, both around current ranges and far from current ranges. A total of 336 pixels of $1 \mathrm{~km} 2$ (scattered into 23 patches) are generated as potential suitable habitat of endemic Leptophryne (Figure 1). The western part of the island has more suitable patches compare to the central and eastern parts. In the western part of Java there are 14 patches. The number is decreasing into the central (5 patches) and eastern part of the island (4 patches). This trend might be affected by the difference in climatic characteristics between the western and eastern parts of the island. The eastern part of Java is known to have a much drier climate compare to western part of the island which forms a type of monsoon forest ecosystem (Whitten et al. 1997; Avia 2013).

The most contributing environmental variables toward the final model of potential suitable habitat of endemic Leptophryne are fluctuation of seasonal temperature $(29.8 \%$ contribution), altitude (29.1\%), land cover $(20 \%)$ and the average temperature of the warmest season (8.4\%). Meanwhile, the other 17 variables have contributed around $12.7 \%$ to the final model. The value of logistic threshold for the final distribution map is 0.33 which defines the higher value as suitable habitat and the lower value as unsuitable for endemic Leptophryne.

The model shows potential suitable habitat of endemic Leptophryne characterized by a relatively stable seasonal temperature with a standard deviation of temperature fluctuation

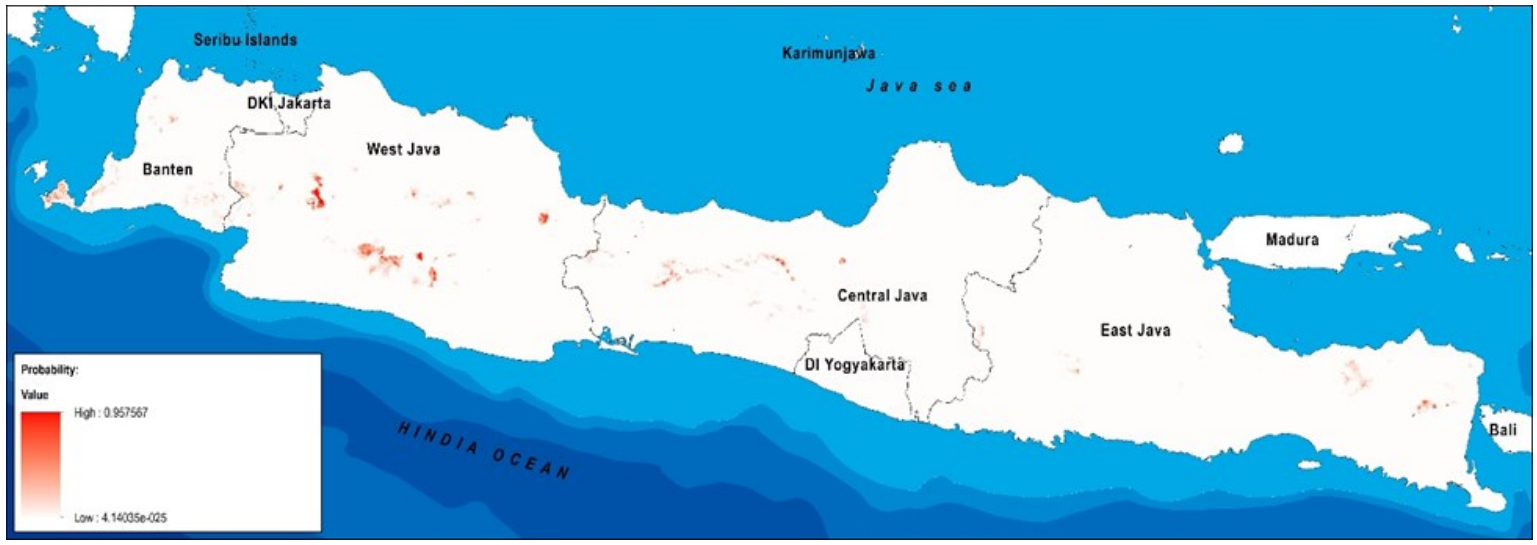

Figure 1. Map of potential suitable habitat distribution of endemic Leptophryne in Java Island (red colored patches as suitable habitat). 
ranging from 2.4-3.2oC (Figure 2). The greater standard deviation shows higher temperature fluctuation which less suitable for the species and reduces the probability of its occurrence. Then, the potential suitable habitat is spread in a mountainous area at above 1200 $\mathrm{m}$ asl. The suitable habitat is a forested area with a relative high vegetation index (NDVI value more than 235 at 1-255 scale). Closed forest canopy prevents the sun from exposing the forest floor, it causes low and stable temperature during day and night. The feature of high elevation and forest cover as the important feature of suitable habitat congruent with previous knowledge on the endemic Leptophryne habitat (Iskandar 1998; Hamidy et al. 2018). In addition, its micro-habitat features waterfall and rock at fast-flowing rocky stream (Hamidy et al. 2018).
Potential habitat in the western part of Java is dispersed mostly inside the conservation area (Figure 3), including Mt. Halimun Salak NP, Mt. Gede Pangrango NP (outside the sample location for this modelling), Mt. Tilu Nature Reserve (NR), Mt. Papandayan NR, and Kamojang NR. Whereas outside conservation area, the potential habitat distributed at northward of Mt. Gede Pangrango NP, north-westward of Mt. Tilu NR, and north-westward Mt. Papandayan NR, and highland area at the border of Kuningan regency (West Java province) and Brebes (Central Java province). Based on potential distribution, there are a relatively large suitable habitat patches in the mountainous area in the southern CianjurBandung-Garut with some continuous habitat patches, especially at Mt. Tilu. The prediction

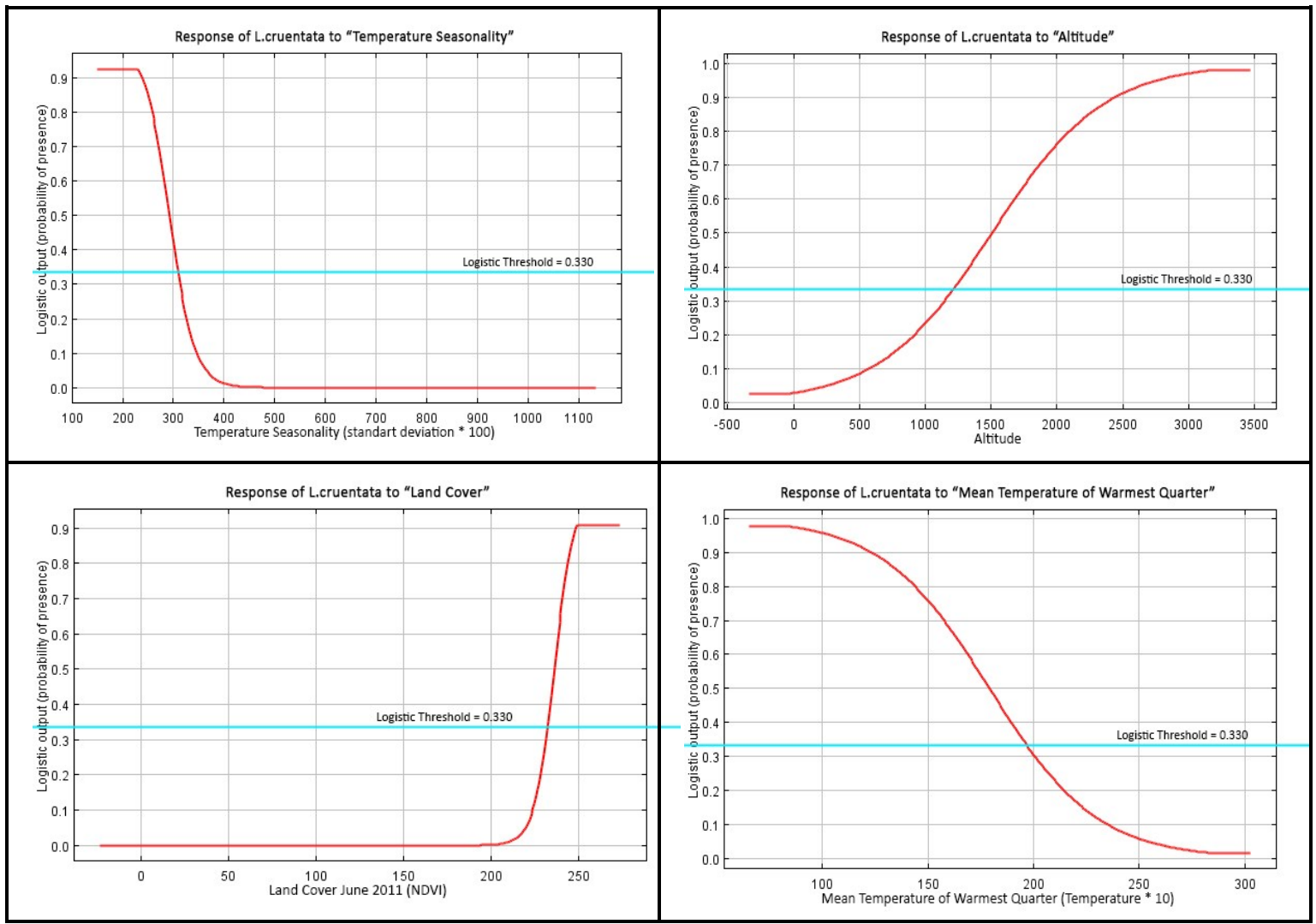

Figure 2. The most contributing environmental variables toward the final model of potential suitable habitat distribution of endemic Leptophryne: temperature seasonality (above left), altitude (above right), land cover (bottom left), and mean temperature of warmest quarter (bottom right). 


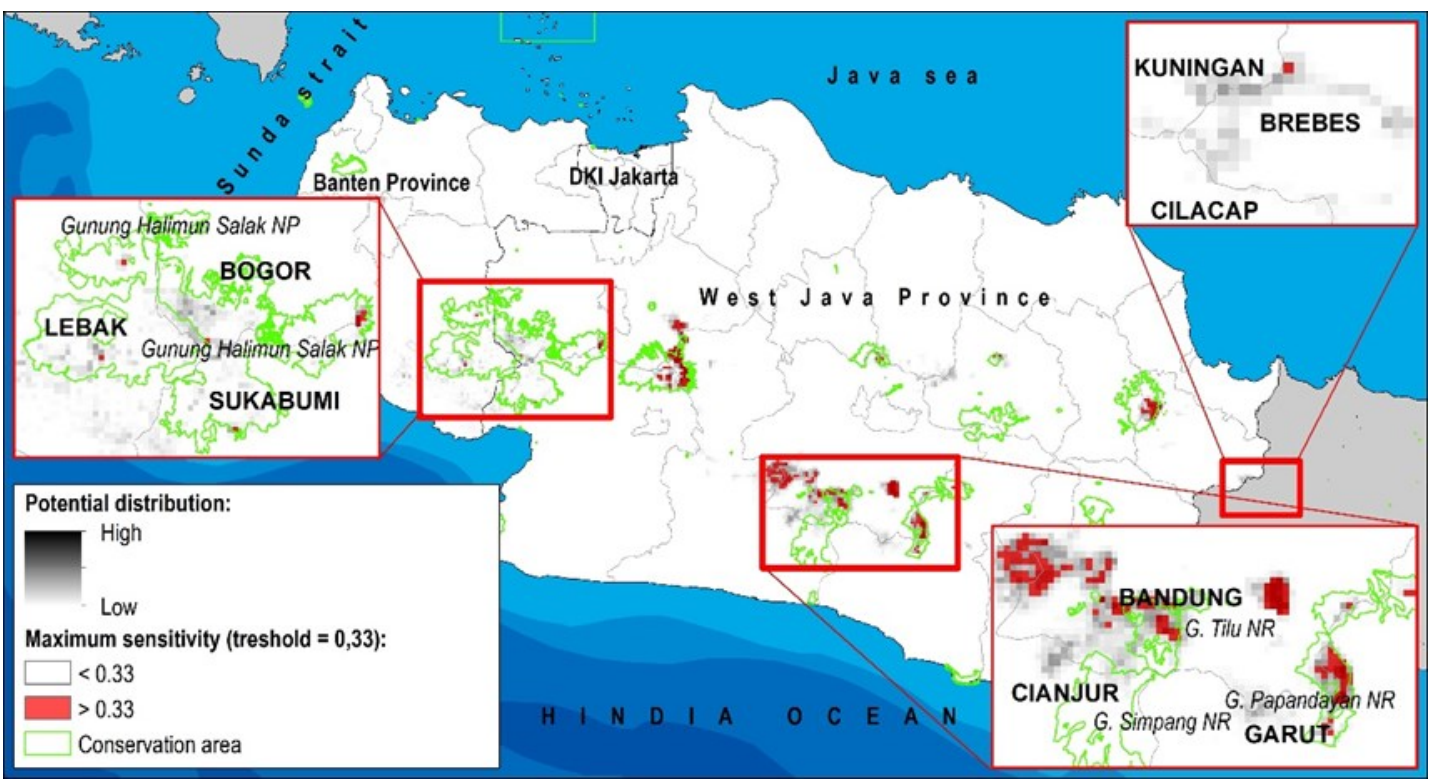

Figure 3. Map of potential suitable habitat distribution of endemic Leptophryne in western part of Java.

of suitable habitat distribution in Mt. Halimun Salak NP confirms this species discovery in Cikeris Block (Kurniati 2013).

The distribution of potential suitable habitat in the central part of the island is located dominantly outside the conservation area, comprising several patches in Mt. Slamet, Dieng Plateau, and Mt. Ungaran. Meanwhile, the potential suitable habitat inside the conservation area only appeared at Gebugan NR (Figure 4). Specimen of endemic
Leptophryne from Guci tourism area located in the northern side of Mt. Slamet was observed on Awu River at 1400m asl (Mumpuni 2014). Relatively large potential suitable habitat is predicted to occur in the south and east slope of Mt. Slamet. However, few surveys in the southern and eastern sides of Mt. Slamet did not record this species (Riyanto 2010; Riyanto \& Trilaksono 2012). Another survey at Petungkriyono (north-west side of Dieng Plateau) close to the predicted distribution area

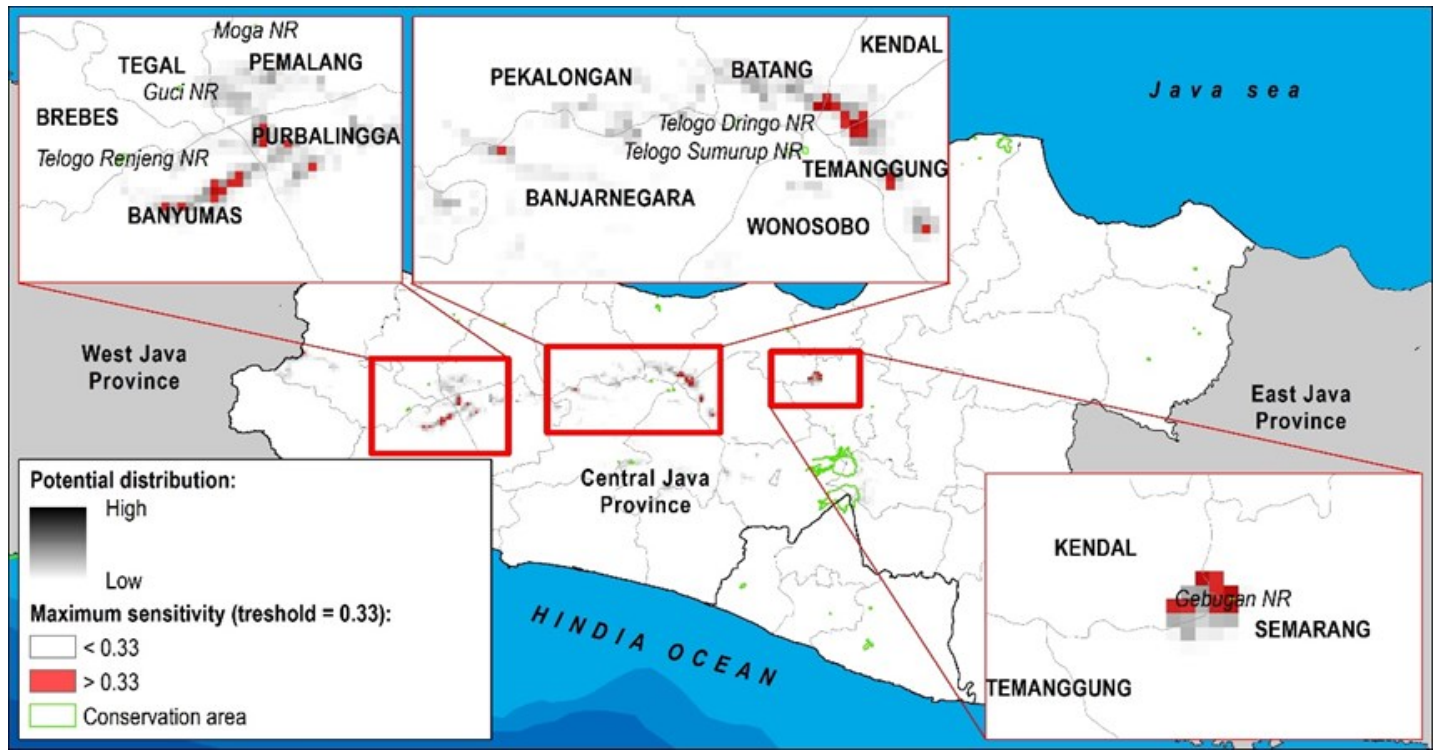

Figure 4. Map of potential suitable habitat distribution of endemic Leptophryne in central part of Java. 


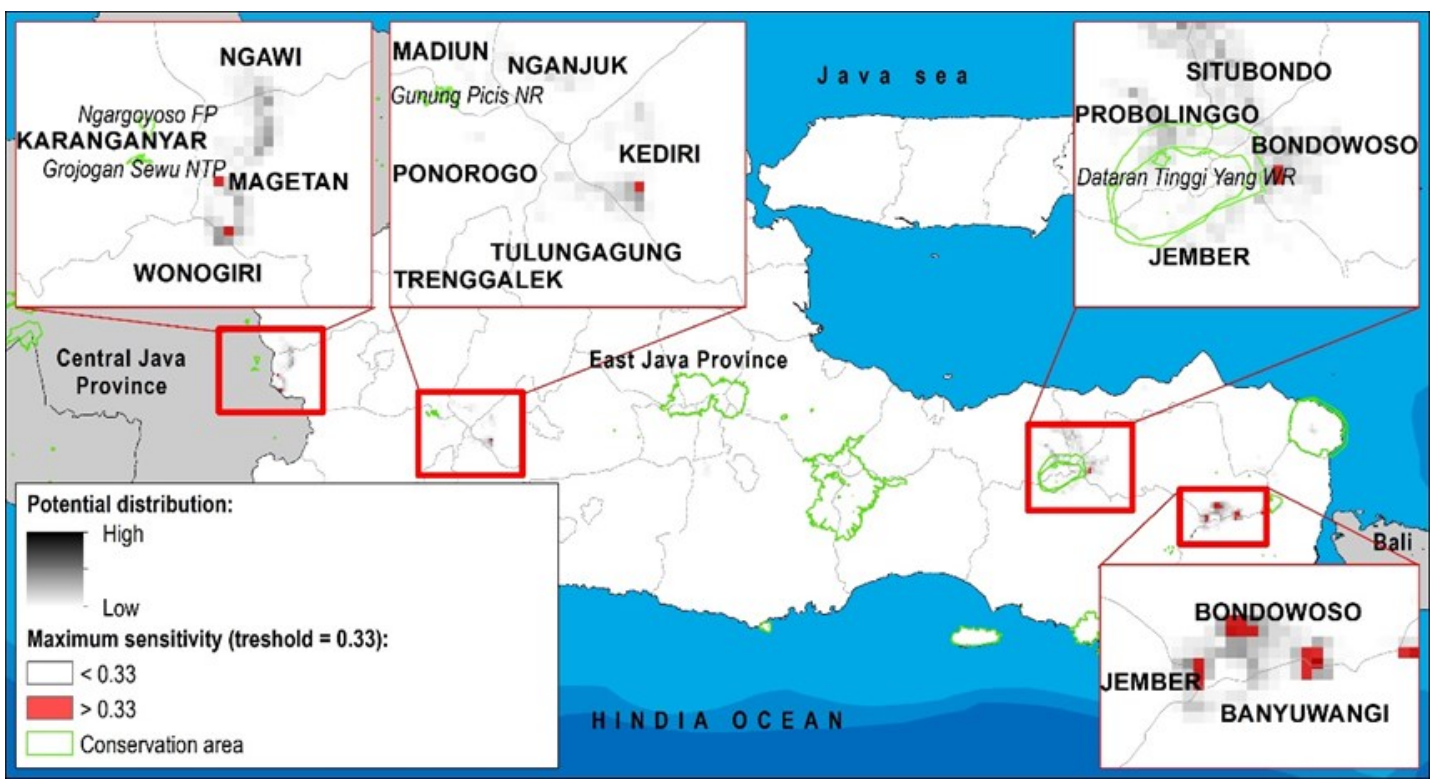

Figure 5. Map of potential suitable habitat distribution of endemic Leptophryne in eastern part of Java.

also did not discover this species (Eprilurahman et al. 2010).

Lastly, the eastern part of Java has smaller and fewer potential suitable habitats compare to the central and western regions (Figure 5). Potential habitat is located in Mt. Lawu which is outside the conservation area, Yang highland Wildlife Reserve, Mt. Raung NR, and Mt. Ijen NR all inside the conservation area. All patches are relatively small and might not be large enough to host the endemic Leptophryne species. To date, there is no information on the herpetofauna of these predicted areas. Elsewhere, the endemic species has not been observed in the southwest border of Bromo Tengger Semeru NP (Septiadi et al. 2018).
Recent new discovery of endemic Leptophryne at several locations outside the previously known range i.e. at Mt. Halimun, Mt. Ciremai, and Mt. Slamet (Kurniati 2003; Setiawan et al., 2014; Mumpuni 2014) shows that this species did not only remain in Mt. Gede. This phenomenon brings about a new perception regarding the possibility to discover this species elsewhere especially at locations with environmental characteristics that is similar to the current actual habitat. Thus, further study is required to collect more information on the occurrence of this endemic species especially at predicted locations based on the modelling. Comprehensive survey on distribution is essential in order to arrange a proper conservation effort in the future for this

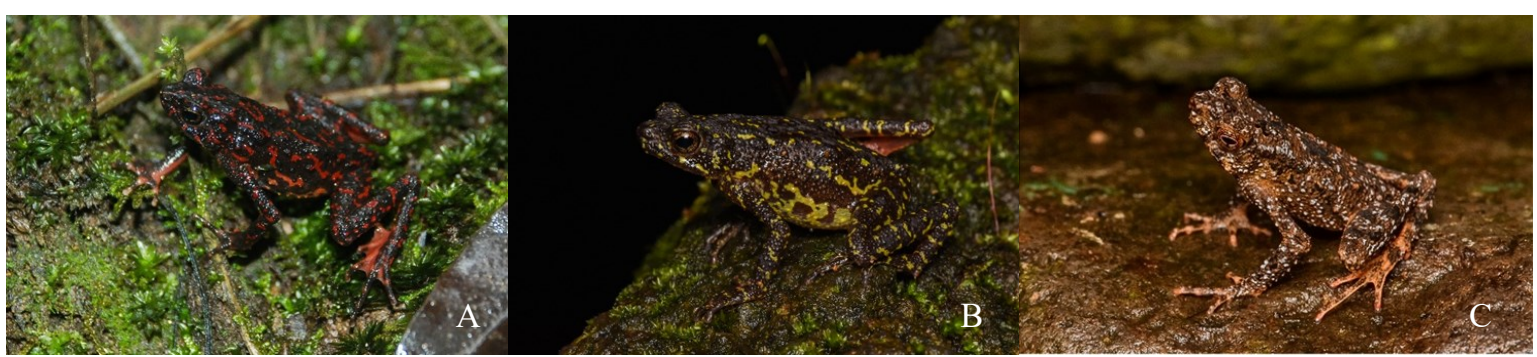

Figure 6. Photo of Leptophryne cruentata (A), L. javanica (B), and L. borbonica (C) (photographs by ADP). 
highly threatened Leptophryne (Hamidy et al. 2018; IUCN SSC ASG 2019).

\section{CONCLUSION}

Habitat characteristics of endemic Leptophryne are rocky fast-flowing rivers (with waterfalls) in an environment with relatively stable weather in mountain forested areas. The model has predicted the occurrence of several patches of suitable habitat beyond its known current range. Potential suitable habitat is distributed scattered at several mountain cross Java, both inside and outside conservation areas. A fairly large potential suitable area was found in a mountainous area at southern of Cianjur-Bandung-Garut region, including Mt. Tilu, Mt. Simpang, Mt. Patuha, and Mt. Papandayan. At the central and eastern part of Java, smaller patches of potential suitable habitat appeared in Mt. Slamet, the north-eastern part of Dieng highland, Mt. Arjuno, and Yang highland. Field survey at the predicted area is urgently needed to complete the distribution information of endemic and highly threatened Leptophryne.

\section{ACKNOWLEDGEMENT}

Part of the study was sponsored by PT Pertamina and CWMBC-ICWRMIP Kemen LHK. We are grateful to Mt. Gede Pangrango NP, Mt. Ciremai NP, BBKSDA Jawa Barat for survey permit. We thank Pak Ace, Pak Harun (Mt. Gede Pangrango NP) and Pak Udun (Mt. Ciremai NP) for the 2013 field survey support. We thank Zaini Rakhman, Anwar Muzakkir, Rully Agus, and PILI staff for their support in many ways. We thank two anonymous reviewers for its comment to improve this manuscript.

\section{REFERENCES}

Avia, L.Q. (2013). Identifikasi Kejadian Monsun Ekstrim di Pulau Jawa dan Sekitarnya. Seminar Sains Atmosfer 2013. Bandung.

Eprilurahman, R., Qurniawan, T.F., Kusuma, K.I. \& Chomsun, H.K. (2010). Studi awal keanekaragaman Herpetofauna di Petungkriyono, Kabupaten Pekalongan, Provinsi Jawa Tengah. Zoo Indonesia, 19(1), 19-30.

Fielding, A.H. \& Bell, J.F. (1997). A review of methods for the assessment of prediction errors in conservation presence/absence models. Environmental Conservation, 24, 38-49.

Hamidy, A., Munir, M., Mumpuni, Rahmania, M. \& Kholik, A.A. (2018). Detection of cryptic taxa in the genus Leptophryne (Fitzinger, 1843) (Amphibia; Bufonidae) and the description of a new species from Java, Indonesia. Zootaxa, 4450(4), 427444.

Hernandez, P.A., Graham, C.H., Master, L.L. \& Albert, D.L. (2006). The effect of sample size and species characteristics on performance of different species distribution modelling methods. Ecography, 29, 773-785.

Hijman, R.J., Cameron, S.E., Parra, J.L., Jones, P. \& Jarvis, A. (2005). Very high resolution interpolated climate surfaces for global land areas. International Journal of Climatology, 25, 1965-1978.

Hirzel, A.H., Hausser, J., Chessel, D. \& Perrin, N. (2002). Ecological niche factor analysis: how to compute habitatsuitability maps without absence data? Ecology, 87, 2027-2036. 
Inger, R.F. (1996). The systematics and zoogeography of the Amphibia of Borneo. Fieldiana Zoology, 52, 1-402.

Inger, R.F. \& Iskandar, D.T. (2005). A collection of amphibian from West Sumatra, with description of new species of Megophrys (Amphibia, Anura). The Raffless Bulletin of Zoology, 53, 133-142.

Iskandar, D.T. (1998). The amphibians of Java and Bali. Bogor: Research and Development Center for Biology, LIPI.

Iskandar, D.T. \& Mumpuni (2004). Leptophryne cruentata. The IUCN Red List of Threatened Species 2004: e.T54815A1207443. Interenational Union of Conservation Nation. Available from: http://iucnredlist.org/details/54815/0

IUCN SSC Amphibian Specialist Group (ASG) (2019). Leprophryne javanica. The IUCN Red List of Threatened Species 2019: e. T138037908A138037921. http:// dx.doi.org/10.2305/IUCN.UK.2019-

1.RLTS.T138037908A138037921.en

Kurniati, H. (2003). Kodok Merah Leptophryne cruentata ditemukan di Taman Nasional Gunung Halimun Jawa Barat. Jurnal Fauna Indonesia, 5, 51-74.

Kusrini, M.D., Yazid, M., Ul-Hasanah, A.U. \& Hamidy, A. (2007). Preliminary study on the distribution and biology of Bleeding Toad, Leptophryne cruentata Tschudi, 1838. In: Kusrini, M.D. (ed) (2007) Frogs of Gede Pangrango: a follow up project for the conservation of frogs in West Java Indonesia. Book 1: Main Report. Technical report submitted to the BP Conservation Programme.
Kusrini, M.D., Skerratt, L., Berger, L., Garland, S. \& Endarwin, W. (2008). Chytridiomycosis in frogs of Mount Gede- Pangrango, Indonesia. Disease of Aquatic Organisms, 82, 187-194.

Kusrini, M.D., Lubis, M.I., Endarwin, W., Yazid, M., Darmawan, B., Ul-Hasanah, A.U., Sholihat, N., Tajali, A., Lestari, V., Utama, H., Nasir, D.M., Ardiansyah, D. \& Rachmadi, R. (2017). Elevation shift range after 40 years: The amphibians of Mount Gede Pangrango National Park revisited. Conservation Biology, 206, 75-84.

Liem, D.S.S. (1971). The frogs and toads of Tjibodas National Park, Mount Gede, Java, Indonesia. Philippine Journal of Science, 100, 131-161.

Mumpuni (2014). Keragaman amfibi dan catatan baru katak di kawasan wisata Guci, Provinsi Jawa Tengah. Zoo Indonesia, 23, 13-19.

Pearson, R.G., Raxworthy, C.J., Nakamura, M. \& Peterson, A.T. (2007). Predicting species distribution from small numbers of occurrence record: a test case using cryptic Geckos in Madagascar. Journal of Biogeography, 34, 102-117.

Phillips, S.J., Anderson, R.P. \& Schapire, R.E. (2006). Maximum entropy modelling of species geographic distributions. Ecological Modelling, 190, 231-259.

Phillips, S.J. \& Dudik, M. (2008). Modeling of species distributions with Maxent: new extensions and comprehensive evaluation. Ecography, 31, 161-175.

Riyanto, A. (2010). Komunitas Herpetofauna dan potensi bagi sektor ekowisata pada Kawasan Ketengger-Baturaden di 
selatan kaki Gunung Slamet, Jawa Tengah. Biosfera, 27(2), 60-67.

Riyanto, A. \& Trilaksono, W. (2012). Komunitas Herpetofauna di Lereng Timur Gunung Slamet, Jawa Tengah. in: Maryanto, I., Noerdjito, M. \& Partomiharjo, T. (editor). Ekologi Gunung Slamet: Ekologi, klimatologi, biodiversitas dan dinamika sosial. Bogor: Pusat Penelitian Biologi-LIPI dan Universitas Jenderal Sudirman, hal. 151-160.

Setiawan, I, Muzakkir, A. \& Saputro, P.B. (2014a). Laporan Kajian Flora dan Fauna di Taman Nasional Gunung Gede Pangrango, Kabupaten Cianjur, Jawa Barat. Unpublished fieldwork report. Laporan CWMBC-ICWRMIP, Bandung.

Setiawan, I., Rakhman, Z., Muzakkir, A., Saputro, B.P. \& Zulkarnaen, I. (2014b). Kajian Biodiversitas dan Pembuatan Kebun Koleksi Anggrek di Taman Nasional Gunung Ciremai. Unpublished fieldwork report, Laporan Akhir-Pusat Informasi Lingkungan Indonesia, Bogor.

Septiadi, L., Hanifa, B.F., Khatimah, A., Indawati, Y., Alwi, M.Z. \& Erfanda, M.P. (2018). Study of reptile and amphibian diversity at Ledok Amprong Poncokusumo, Malang East Java. Biotropika: Journal of Tropical Biology, 6 (2), 45-53.

Smith, D., Lucey, B., Waller, L.A., Childs, J.E. \& Real, L.A. (2002). Predicting the spatial dynamics of rabies epidemics on heterogenous landscapes. Proceedings of the National Academy of Sciences of the United States of America, 99, 36683672.

van Kampen, P.N. (1923). The Amphibia of the Indo-Australian Archipelago. E.J. Brill: Leiden.

Whitten, T., Soeriaatmadja, R.E. \& Afiff, S.A. (1997). The Ecology of Java and Bali. UK: Oxford University Press. 